\title{
Zoophytophagy in Predatory Hemiptera
}

\author{
Jorge Braz Torres $^{1 *}$ and David W. Boyd ${ }^{2}$ \\ ${ }^{I}$ Departmento de Agronomia, Entomologia; Universidade Federal Rural de Pernambuco; Av. Dom Manoel de Medeiros; \\ 52171-900; Recife - PE - Brasil. ${ }^{2}$ Southern Horticulture Laboratory; USDA-ARS; P.O. Box 28; Poplarville, MS \\ 39470 - USA
}

\begin{abstract}
Predaceous hemipteran feeding on different trophic levels have raised questions about their ecology and role in biological control. Therefore, specific adaptations allowing them to simultaneously use plants and animals as sources for their nutritional requirements are important. Enzymatic variability in predatory hemipterans has been suggested as the basic adaptation for convergent or divergent to omnivory. Thus, the salivary enzymatic complexes of predatory hemipterans have been furnished a partial understanding of the mechanisms permitting switching between plant and animal food sources. In this study, a discriminatory analysis was performed to attribute trophic habits to each insect investigated based on the presence and absence of salivary enzyme combinations. Although peptidase is found in all tested predatory hemipterans' salivary glands, it is not a distinguishing enzyme because it has been found in phytophagous species as well. However, the presence of peptidase and amylase activity in hemipteran salivary glands is considered to be an explanation for these insects' ability to switch their diet, predators feeding on plants (amylase) and herbivores taking prey (peptidase).
\end{abstract}

Key words: Feeding behavior, salivary glands, phytophagy, zoophagy, biological control

\section{INTRODUCTION}

Opportunistic omnivores, being either zoophagous or phytophagous, can be placed near the extremes of the continuum between phytozoophagy (i.e., prey-taking herbivores) and zoophytophagy (plant-feeding carnivores). Because plant and prey diets differ greatly in their chemical composition, mixing them in the diet requires specific physiological and morphological adaptations, primarily from digestive enzymes (Cobben, 1978).

The Hemiptera contains families that are obligate zoophages (e.g., Reduviidae, Phymatidae, and Nabidae) with great contribution to natural and applied biological control of pests, and obligate phytophages (e.g., Tingidae and Coreidae) (Coll and Guershon, 2002). Among the predatory hemipterans, zoophytophagy varies considerable. For example, the two-spotted soldier bug, Perillus bioculatus (F.) (Pentatomidae, Asopinae), feeds on different prey species in the laboratory, but is usually found in the field associated with coleopterous insects, specializing on chrysomelid larvae (Saint-Cyr and Cloutier, 1996). In contrast, another pentatomid, the predatory stinkbug, Podisus nigrispinus (Dallas) (Pentatomidae, Asopinae), has been reported feeding on more than 30 insect species from different orders (Torres et al., 2006). However, both species feed on various plant species, but cannot survive on plants alone (Tamaki and Butt, 1978; Oliveira et al., 2002). On the other hand, Dicyphus tamaninii Wagner (Miridae) can attain adulthood on plants with or without prey (Saleh and Sengonca, 2001). In the

*Author for correspondence: jtorres@ depa.ufrpe.br 
presence of preferred prey (ca. thrips, aphids and whiteflies), D. tamaninii is an important predator (Wheeler, 2000), but in the absence of prey or at high populations, they can be pests of tomato and green pepper (Alomar and Albajes, 1996). Likewise, Dicyphus hesperus Knight (Miridae), although considered a biological control agent, can switch its diet on greenhouse whiteflies and tomato plants, and when provided a diet consisting only of prey, they exhibit very low survival (Gillespie and McGregor, 2000).

Predatory hemipterans, having access to plant materials, exhibit greater survival, larger body weight, greater fecundity, and live longer, and shorter developmental time (Stoner, 1970; Naranjo and Stimac, 1985; Ruberson et al., 1986; Valicente and O'Neil, 1995; Oliveira et al., 2002; Evangelista et al., 2004). Those species exhibiting improved life history traits might benefit as a result of acquiring extra sources of nutrients and steroids, such as campesterol, for synthetizing molting hormones (Thummel and Chory, 2002). Campesterol is found in plants, especially in the legume family. Legumes are known hosts for phytophagous hemipterans and provide the best results as supplementary food for predaceous hemipterans (Valicente and O'Neil, 1995; Coll, 1998; Evangelista et al., 2004). Under this scenario, predatory hemipterans presumably ingest certain nutrients or hormones derived from plants which they cannot derive from prey. To take advantage, however, these predatory hemipterans are required to balance amylase and peptidase according to food source use, so these enzymes have been called trophic enzymes (Cohen and Hendrix, 1992). Consequently, the enzymatic profile of predatory hemipterans plays an important role in the predation process. The process begins by the predator selecting a suitable prey for their suite of enzymes, digesting prey contents prior to ingestion (ca., salivary enzymes) (Cohen, 1996), further digesting it in the gut (ca., gut enzymes) and then converting the food to energy for other needs (Applebaum, 1985; Terra and Ferreira, 1994). Thus, this review presents a general perspective of the feeding behavior of predatory hemipterans that can use plants and animals for food, and discusses the importance of this omnivorous behavior to the population maintenance in the field. Also, the implications for pest management, especially related to host plant resistance will be discussed.

Because predatory hemipterans occur over a wide range of habitats, terrestrial predatory species of known importance for pest management is the focus of this review.

\section{MATERIAL AND METHODS}

In this study omnivory was considered as feeding on different trophic levels. In a broad sense, omnivory in hemipterans has attracted attention due to conflict about how predation evolved and the role it has played on community structure (i.e., bottom-up effects - plant mediated and top-down effects predator mediated). The ecological aspects of omnivory have been discussed by Agrawal (2003) who described omnivory to have evolved in Hemiptera from a propensity to feed on pollen and seeds as more $\mathrm{N}$-concentrated food, hence, closer to animal tissues rather than from a propensity to feed on leaves and other plant structures (Eubanks et al., 2003). Although polyphagy was stated to be the transient step to predation, an adaptation on enzymatic profile would have been required to efficiently explore different diets. Therefore, salivary enzyme radiation should occur before a diet shift, especially in predatory hemipterans which rely mainly on extra-oral digestion of the food. This fact is prominent with secretions of enzymes such as amylase and phospholipase by predatory species such as Podisus maculiventris and Geocoris punctipes belonging to the Pentatomomorpha, a monophyletic group comprised of ancestrally herbivorous species.

Salivary enzyme complexes allow predatory hemipterans to use diet sources from different trophic levels (Table 1). Based on enzyme profiles of 14 selected hemipterans with studies on salivay enzymes, one strict predator [Platymeris rhadamanthus (Reduviidae)], one strict phytophagous [Poecilocapsus lineatus (Miridae)] and 12 species with records of switching diet were selected. Discriminatory Analysis was performed to attribute trophic habits to each insect based on their salivary enzyme combinations. Prior to the analysis, species were ranked into two feeding habits - phytophage $(\mathrm{P})$ or zoophage $(\mathrm{Z})$ - based on predominant behavior described in life history studies and feeding observations reported in the literature. Salivary enzymes of strict zoophages and strict phytophages were used to set the outer limits for zoophagy and phytophagy and to allow the distribution of the other species within the feeding continuum. Further, presence or absence of pectinase or phospholipase was set as the determinatory enzymes for phytophagy or zoophagy, respectively (Table 1). 
Table 1 - Major enzymes detected in the salivary glands of selected hemipteran species investigated (+, presence; -, absence and; open space means no information available) and feeding continuum ranking prior and after enzymes consideration through the analysis.

\begin{tabular}{|c|c|c|c|c|c|c|c|}
\hline Species (Family) & $\begin{array}{l}\text { Feeding } \\
\text { habit* }\end{array}$ & Peptidase $^{* *}$ & Phospholipase & Amylase & Pectinase & References & $\begin{array}{l}\text { Feeding } \\
\text { trends* }\end{array}$ \\
\hline Zelus renardii (Reduviidae) & $\mathrm{Z}$ & + & + & + & - & 1,2 & $\mathrm{Z}$ \\
\hline Sinea confusa (Reduviidae) & $\mathrm{Z}$ & + & + & - & - & 2,3 & $\mathrm{Z}$ \\
\hline $\begin{array}{l}\text { Platymeris rhadamanthus } \\
\text { (Reduviidae) }\end{array}$ & $\mathrm{Z}$ & + & + & & - & 4 & $\mathrm{Z}$ \\
\hline Nabis alternatus (Nabidae) & $\mathrm{Z}$ & + & + & + & - & 2 & $\mathrm{Z}$ \\
\hline $\begin{array}{l}\text { Geocoris punctipes } \\
\text { (Geocoridae) }\end{array}$ & $\mathrm{Z}$ & + & + & + & - & 2,3 & $\mathrm{Z}$ \\
\hline $\begin{array}{l}\text { Podisus maculiventris } \\
\text { (Pentatomidae) }\end{array}$ & $\mathrm{Z}$ & + & + & + & - & 3,5 & $\mathrm{Z}$ \\
\hline Lygus hesperus (Miridae) & $\mathrm{P}$ & + & - & + & + & $6,7,8$ & $\mathrm{O}$ \\
\hline Lygus lineolaris (Miridae) & $\mathrm{P}$ & + & - & + & + & 8 & $\mathrm{O}$ \\
\hline Lygus rugulipennis (Miridae) & $\mathrm{P}$ & + & & + & + & 9 & $\mathrm{O}$ \\
\hline Creontiades dilutus (Miridae) & $\mathrm{P}$ & + & & & + & 10,11 & $\mathrm{O}$ \\
\hline $\begin{array}{l}\text { Orius insidiosus } \\
\text { (Anthocoridae) }\end{array}$ & $\mathrm{Z}$ & + & & + & & 12 & $\mathrm{Z}$ \\
\hline $\begin{array}{l}\text { Deraeocoris nigritulus } \\
\text { (Miridae) }\end{array}$ & $\mathrm{Z}$ & + & & - & + & 13 & $\mathrm{O}$ \\
\hline $\begin{array}{l}\text { Poecilocapsus lineatus } \\
\text { (Miridae) }\end{array}$ & $\mathrm{P}$ & - & & - & $+^{* * * *}$ & 7 & $\mathrm{P}$ \\
\hline $\begin{array}{l}\text { Deraeocoris nebulosus } \\
\text { (Miridae) }\end{array}$ & $\mathrm{Z}$ & + & & - & + & 14 & $\mathrm{O}$ \\
\hline
\end{tabular}

"Z, zoophage; P, phytophage and; O, omnivore. ${ }^{* *}$ (Trypsins, Chymotrypsins, carboxypeptidases, cathepsin), ***as exopectinase.

${ }^{1}$ Cohen (1993), ${ }^{2}$ Cohen (1996), ${ }^{3}$ Cohen (1990), ${ }^{4}$ Miles (1972), ${ }^{5}$ Stamopoulous et al. (1983), ${ }^{6}$ Strong and Kruitwagen (1968), ${ }^{7}$ Cohen and Wheeler (1998), ${ }^{8}$ Agusti and Cohen (2000), ${ }^{9}$ Laurema et al. (1985), ${ }^{10}$ Hori and Miles (1993), ${ }^{11}$ Colebatch et al. (2001), ${ }^{12}$ Zeng and Cohen (2000b), ${ }^{13}$ Boyd Jr (2003), ${ }^{14}$ Boyd Jr et al. (2002).

Using enzymes reported as present or absent (i.e., not detected when tested)] from the salivary glands of predatory hemipterans with known feeding behaviors, the hypothesis that the composition of salivary enzymes could place them accurately in a continuum between the strict zoophagy and strict phytophagy was tested. The following salivary enzymes of 14 hemipteran species for the Discriminant Analysis were used: peptidases (trypsins, chymotrypsins, carboxypeptidases and cathepsins), phospholipase, amylase and pectinase. Canonical discriminatory analysis is an indirect ordination technique that reduces dimensionality of the original set of qualitative and quantitative variables and can be used to illustrate the relative positions of target variables into two dimensions of the most contributing variables (SAS Institute, 1999-2001). Three dimensions (canonical variates: zoophagy, omnivory, and phytophage) were tested based on the presence/absence of salivary gland enzymes using the
CANDISC procedure of SAS (SAS Institute, 19992001).

\section{RESULTS}

Discriminatory analysis selected three distinct groups: two groups that shared three species, and the third group with an isolated species. Poecilocapsus lineatus, a strict phytophage, did not have peptidases or amylases in its salivary glands (Cohen and Wheeler, 1998), generated the complete isolated group. Group distinction with exception of $P$. lineatus was only possible at $10 \%$ significance. The $\mathrm{x}$-axis (CAN 1) indicated trends between phytophagy and zoophagy with the far left species being more phytophagous and the far right species being more zoophagous. The y-axis (CAN 2) indicated the insects ability towards omnivory with the species at the top tending to be more omnivorous and those at the 
bottom less omnivorous. Thus, $P$. lineatus was placed far left in the x-axis (CAN 1) and negative in the $y$ axis (CAN 2), hence it was considered a phytophagous species with a weak ability for omnivory. This placement on the discriminatory scale agreed with its observed feeding behavior (Cohen and Wheeler, 1998; Hori, 2000). Species characterized with gray symbols (Fig. 1) showed a positive contribution to the first canonical axis, indicating zoophagy. Four of them were positive on the second canonical axis ( $G$. punctipes, Orius insidiosus, $P$. maculiventris, and $Z$. renardii) showing a higher tendency for omnivory than the other three species ( $N$. alternatus, $P$. rhadamanthus, and $S$. confusa). Species with open symbols in the positive range of the second canonical axis (C. dilutus, D. nigritulus, and $L$. rugulipennis) were considered phytophagous with a tendency towards omnivory. The remaining three species with closed symbols (D. nebulosus, $L$. hesperus, and L. lineolaris) represented omnivorous species that could either be phytozoophagous or zoophytophagous.

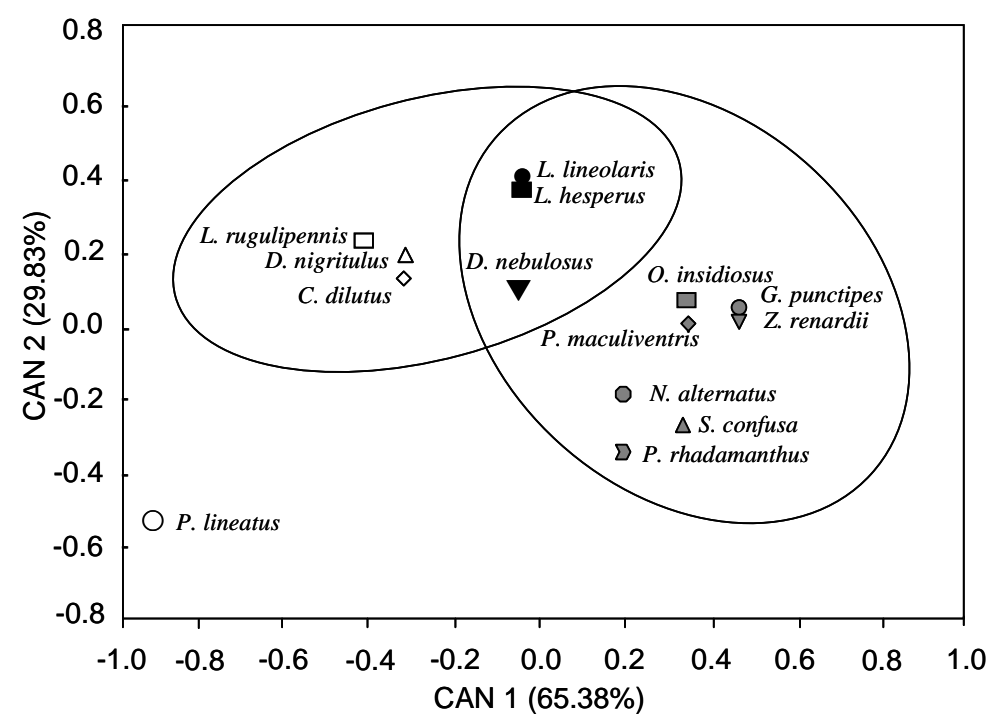

Figure 1 - Ordination diagram showing the discrimination among 14 species of hemipterans exhibiting strict plant ( $P$. lineatus), animal ( $P$. rhadamanthus) and mixed plant and animal diet. The two first canonical axes explained $91.39 \%$ of total variance. The symbols are the centroid of species and are the class means canonical variates. Clustering groups were considered at $10 \%$ level of significance to show trending on feeding behavior characterized by the symbols (open indicating phytopaghy; closed indicating omnivory and; gray color indicating zoophagy).

\section{DISCUSSION}

\section{Predatory switching enzymes}

The results of analysis showed departure of the supposed original feeding behavior in both ways from phytophagy to omnivory and from zoophagy to omnivory. However, only Deraeocoris species ranked as zoophagous were moved to an omnivorous feeding behavior trend (Table 1). At this point, the role of salivary enzymes for these mirid bugs is important. For these bugs, among other functions, pectinase is assumed to have a function as a plant tissue soften for oviposition (Ferran et al., 1996; Boyd Jr et al., 2002; Boyd Jr, 2003). However, predaceous mirids such as Dicyphus hesperus and D. tamanii have the ability of trophic switching, thereby they are able to attain adulthood on either animal or plant diet (Gillespie and McGregor, 2000; Saleh and Sengonca, 2001). Therefore, besides softening plant tissues to allow egg deposition, in the present analysis, it was assumed that pectinase also played an important role in stylet penetration of plant tissues and disrupting plant cells prior to ingestion. However, pectinase is probably only an important enzyme among hemipterans in the family Miridae (Hori, 2000), albeit there is exception (see Campbell and Shea, 1990).

The analysis result was quite surprising for two cimicomorphans with a long heritage of zoophagy. Zelus renardii was closer to omnivory, being closer to $G$. punctipes, $P$. maculiventris and $O$. insidiosus, 
while $N$. alternatus was placed closer to strict zoophagy than omnivory. Species of Nabis and the other three species for this grouping are known to have an enhancement in their performance when using a mixed diet of animal and plant, which indicates the importance of omnivory for these species. Placement of $Z$. renardii would be expected to be closer to $S$. confusa and $P$. rhadamanthus, two strict predator species. This, however, was a result of the presence of amylase secretion in the salivary gland of $Z$. renardii but not detected in $N$. alternatus, $S$. confusa and $P$. rhadamanthus. Therefore, the degree of activity of these enzymes coupled with presence/absence would better place species into a feeding continuum. For instance, salivary gland secretions of G. punctipes exhibit amylase activity but much lower than that activity detected in the phytophagous bug, L. hesperus (Zeng and Cohen, 2000a).

The enzymatic content of the saliva of any particular species cannot be assumed to be constant. Evidence for the variation in content is available, especially peptidase, in relation to the amount of protein in the diet (Miles, 1972). Enzymatic adaptation can also be according to the developmental stage. For example, in the second and third instars of $P$. maculiventris, the enzyme activity of the midgut is centered on amylase, esterase-lipase, phosphatase, $\alpha$-glucosidase, leucine arylamidase and $\mathrm{N}$-acetyl- $\beta$-glucosaminidases, while fifth instar and adults midgut cells secrete a complex of 19 enzymes, with high activity found for at least 14 of them (Stamopoulos et al., 1993). After the 3rd instar, $P$. maculiventris shows high midgut activities of $\beta$-glucosidase and amylase, indicating their ability to use $\beta$-glucosides such as salicine, amygdaline, arbutine, and gentibiose, among others from plant starch digestion (Stamopoulos et al., 1993). The high amylase activity not only indicates its potential to digest the starch, the major glycoside reserve found in plants, but also other polysaccharides and dextrines from glycogen, the major animal cell glycoside reservoir (Cohen, 1990; Stamopoulos et al., 1993) what correlates with amylase presence in neotropic Asopinae species Podisus nigrispinus and Brontocoris tabidus (Oliveira et al., 2006; Azevedo et al., 2007).

Lygus hesperus is a good example of a phytophagous species with a propensity to switch the feeding between the plant and animal. The fact that $L$. hesperus tested positive for salivary pectinase and amylase (Agusti and Cohen, 2000; Zeng and Cohen, 2000a) indicates that it is clearly adapted biochemically for plant consumption and it is considered a serious pest of many crops. However, the presence of a venom and phospholipase $\mathrm{A}_{2}$ activity (Cohen, 1996; 1998a) indicate an advanced state of adaptation for predation. Lygus lineolaris, on the other hand, has higher amylase activity in salivary glands than $L$. hesperus, but observations suggested that both species are well suited for extracting otherwise insoluble starch from plant material by using extra-oral digestion (Agusti and Cohen, 2000). Proteases and lipases in the salivary glands are potentially useful for either phytophagy or zoophagy. Conversely, pectinase is clearly adaptive for phytophagy (Hori, 2000), while amylase plays important role on starch utilization and, hence, allowing predators feeding on different trophic levels (Cohen and Hendrix, 1992). Phsopholipases $A_{1}$ and $\mathrm{A}_{2}$ seem adaptation for predation (Cohen, 1998a), and are not reported from phytophagous species (Hori, 2000).

Based on the analysis from salivary gland enzyme composition, $P$. maculiventris and $G$. punctipes showed a strong ability to switch their diet on plant and animal. These species exhibited both trypsin-like enzyme as adapting to predation, and amylase as adapting to digest plant contents and glycogen derivates from prey. However, neither $P$. maculiventris nor $G$. punctipes was positive for pectinase. This indicated that both species were weak in dilacerating plant tissues, which was the major action of pectinase (Terra and Ferreira, 1994; Hori, 2000).

\section{Enzymatic profile and feeding behavior}

The types of digestive enzymes, especially those of salivary origin, are highly correlated with the feeding habitats of hemipterans (Miles, 1972; Hori, 1975; Agusti and Cohen, 2000; Hori, 2000; Zeng and Cohen, 2000a; 2000c; Boyd Jr et al., 2002; Boyd Jr., 2003). Peptidases and phospholipases are present in salivary gland extract or saliva of predatory hemipterans unable to complete development exclusively on a plant diet such as Z. renardii and $G$. punctipes. Also, triacylglycerol lipases, a typical enzyme to act on lipids produced by plant seeds, have been found in salivary gland extracts of predators (Rastogi, 1962; Cohen, 1990). This deserves more study, since lipase action is believed to occur mainly in the midgut (Terra, 1990) to digest triacylglycerol from prey items but not in the salivary gland. However, peptidases and lipases are not restricted to predatory hemipterans. Several mesophyll- and seed- 
feeders have been shown to have salivary peptidases as well as lipid-digesting enzymes (Miles, 1972; Hori, 2000). Therefore, feeding on plant and prey requires specialization of mouthparts, digestive tract, enzyme complexes, and biochemical pathways (Cohen, 1990; Terra and Ferreira, 1994). Predatory hemipterans do not confine their ingestion to the body fluids of their prey. They use a solid-to-liquid feeding method and attack the nutrient-rich organs and tissues of their prey (Cohen, 1995; 1998a; Swart and Felgenhauer, 2003). A predaceous hemipteran would have to consume between three and 20 times as much biomass of hemolymph as it would mixed prey biomass (i.e., tissues and hemolymph combined) to get a given amount of protein, fat, or cholesterol. By consuming only the hemolymph, it would get less than one third of the protein biomass available in solid tissues, one tenth of the fat, and one nineteenth of the cholesterol (Cohen, 2000).

\section{Hemipteran salivary enzymes and handling time}

Handling time is a critical time for predators in general, but specially for predaceous with extra-oral digestion. Predators with this type of feeding behavior such as predatory hemipterans capture their prey items, insert their stylets into the prey, injecting venom and digestive enzymes, and mechanically disrupt prey with their stylets and chemically disrupt tissues with macerating enzymes [e.g., peptidases and phospholipases (Cohen, 1995)]. Thus, enzymes play an important role during handling time and hence prey selection and number of prey consumed.

The prey liquefaction time depends on the kinetics of salivary enzymes and on the mechanical efficiency of the stylets. In addition, long stylets with smaller diameter increase the access of the bundle to cryptic prey parts. The viscosity of the prey is exponentially related to the nutrient concentration and is, therefore, one of the most mutable components of the food ingestion system (Cohen, 1998b). The salivary gland complex contributes in two ways to viscosity reduction of prey fluids: (i) by producing enzymes that reduce the size of macromolecules (Cohen, 1995), and (ii) by secreting copious diluted saliva (Miles, 1972). Thus, the saliva's role in reducing the prey viscosity is by offering watery saliva to hydrolyze macromolecules (Cohen, 1998b).

Terrestrial hemipteran predators have evolved in both the Pentatomomorpha (Geocoridae and Pentatomidae) and Cimicomorpha (Reduviidae, Miridae, Anthocoridae, and Nabidae). Members of the latter group exhibit a shorter handling time, which is attributed to differences in the activity of digestive enzymes (Haridass and Ananthakrishnan, 1981; Cohen, 1998b). Salivary peptidases are found in both infraorders, but those isolated from cimicomorphs have far greater rates of enzymatic activity than those from pentatomomorphs. Salivary amylases are found in both groups but are more consistently present in pentatomomorphs than in cimicomorphs. For this reason, is expected that plant feeding plays more role for pentatomomorphs (ca. Geocoris, Podisus, etc) than cimicomorphs (ca. Orius, Nabis, etc). Salivary lipases and phospholipases are found in both infraorders, but hyaluronidases have been reported only in the saliva of cimicomorphs (Edwards, 1961; Laurema et al., 1985; Cohen, 1998b).

Dissections of prey 15-30 min after feeding provide visual evidence of differences in the relative digestive ability of cimicomorphan and pentatomomorphan saliva. Internal structures of prey fed on by cimicomorphs appear to be more rapidly liquefied than those fed on by pentatomomorphs, and these differences are also obvious when the kinetics of salivary peptidases are compared (Cohen, 1996). Relative rate of hydrolysis of digestive enzymes from salivary glands of cimicomorphs is higher than pentatomomorphs (Cohen, 1998b). Also, species of cimicomorphan have the digestive enzyme elastase (an alkaline peptidase that complements the actions of trypsin and chymotrypsin) in their salivary complex but it has not been detected in pentatomomorphan yet (Zeng and Cohen, 2001).

The potent salivary secretions amplify predaceous hemipterans' food selectivity and their efficient use of prey materials. All hemipteran species that switch between animal and plant diets show a definite predigestive activity with peptidases and phospholipases and rather weak activity with triacylglycerol lipases (Cohen, 1996). Peptidases and phospholipases are instrumental in disrupting tissues and cells, releasing nutrients that can be taken up by the watery saliva (Cohen, 1990), while amylases may be useful in plant feeding or in digestion of prey glycogen (Boyd Jr et al., 2002).

\section{Implications, conclusions and future needs}

Studies with predator enzymatic profiles are scarce and it is an open avenue for research with great potential of contribution through a basic understanding of hemipteran feeding behavior, ecology, plant damage, and biological control by improving the chances of artificial diet development and utilization. The salivary enzyme profile can be an 
indicative of source of nutrient to be added in diet improvement (Freitas et al., 2006).

Feeding on plant requires that the predator overcome plant protein- and amylase-inhibitors, which are active against insect proteolitic enzymes (Oppert, 2001). Various $\alpha$-amylase and peptidase inhibitors (PIs) present in seed and vegetative organs of plants are able to act as limiting regulators of phytophage number and are involved with pest enzymes in hostherbivore relationship (Konarev, 1996). Therefore, understanding on PIs functions have been considered a potential avenue to transgenic plants development against plant sap feeders (Hemiptera), which are unaffected by current transgenic plants expressing toxin from Bacillus thuringiensis. On the other hand, transgenic plants may impose a problem in the future for predatory hemipterans that switch between animals and plants (Ashouri et al., 1998; Bell et al., 2003).

Pectinase is a distinguishing enzyme for phytophagy showing that species secreting this enzyme are very well equipped for macromolecular destruction of plant cells via the salivary apparatus (Laurema et al., 1985; Agusti and Cohen, 2000; Hori, 2000). In contrast, the presence of amylase activity in the salivary glands of zoophages is suggestive of their ability to feed on plant and acquires nutrients if necessary. The trypsin-like enzyme in the salivary gland complex permits extra-oral digestion for use of proteins in animal food. Trypsin-like enzymes are very active in the salivary gland of the reduviid $Z$. renardii, which is considered an important aspect of zoophagous capability in this obligatory predator (Cohen, 1993).

Enzymatic profiles cannot, however, serve as an obvious tool of food range recognition. For instance, the saliva of some mesophyll and seed-feeders, such as Oncopeltus fasciatus (Lygaeidae) has been reported to contain peptidases and lipases (Miles, 1972). This is probably the result of an overlap between enzymes required to digest nutrients from different sources. Moreover, insights about the capacity of enzyme secretion induction by food source ingested in Hemiptera have been gained (Zeng and Cohen, 2001). Amylases, for example, hydrolyze starch, but they also digest polysaccharides such as glycogen and dextrines, which are found in animal cells. Lipases act on a range of lipids type found in plants, such as triacylglycerol lipase that in the midgut acts primarily on triacylglycerol found abundantly in seeds, and presumed to be important for hemipteran's feeding on seeds (Klowden, 2002). Hemipterans considered phytozoophagous (e.g., $L$. hesperus and $L$. lineolaris) and those zoophytophagous (e.g., $D$. nebulosus, D. tamanii) possess salivary pectinases and amylases that are indicative of plant consumption or even strict phytophagy, and relatively high levels of peptidases, which differ from specialized carnivores (Agusti and Cohen, 2000; Zeng and Cohen, 2000a; 2000b). It is possible that this highly developed enzymatic profile allows them assimilation of nutrients beyond those readily available in plant tissues. For example, tracking of radiolabeled isotopes from the plant showed that the insidiosus flower bug, $O$. insidiosus, feeds primarily on the mesophyll and xylem (Armer et al., 1998), thus acquiring moisture and nutritional elements to supplement its prey diet. These findings are supported by the amylase content in the saliva of this species (Zeng and Cohen, 2000a). Finally, based on enzyme induction and presence of unexpected enzyme in both feeding continuums (phytopaghe and zoophage), hemipteran seems to have predisposition to secrete a large profile of enzymes and enzyme secretion that can be biased by food source. This hypothesis might be solved by tracking enzyme activities along multiples generations or life stages of a species confined on a diet representing opposite extremes of the feeding continuum, plant-feeders imbibing prey (more prey than plant) and predators feeding on plants (more plant than prey). Based on its ecology, D. tamanii e $D$. hesperus seems to be ideal species to test this hypothesis since they reache adulthood on either plants or prey separately.

Contents of salivary gland have helped to elucidate the feeding behavior not only for herbivores and predators, but also for hematophages (Valenzuela and Ribeiro, 1998), although definitive conclusions could not be drawn. Some results reported in this review could be revised by more refined enzymatic analyses methods. The lack of a standard procedure for enzyme detection and activity has impeded some comparisons about the degree of specific substrate activity; hopefully the use of specific substrate tests and advances in chemical analyses would provide better conditions to certify the presence of possible discriminatory enzymes, which better support the two-way flux between use of plants and animals as food sources for hemipteran predators. In addition, histological and biochemical studies should be explored for providing more details on salivary glands capacity to recover enzyme production between the meals and their possible continuous secretions allowing hemipteran predators, such as phytophagous, to take food from plant by continuous feeding. 


\section{ACKNOWNLEDGMENTS}

We are grateful to John R. Ruberson (UGA-Tifton, USA) and Walter P. Terra (USP-São Paulo, Brazil) for their helpful suggestions and "Coordenação de Aperfeiçoamento de Pessoal de Nível Superior" (CAPES Foundation, Brazil) and "Conselho Nacional de Desenvolvimento Científico e Tecnológico (CNPq).

\section{RESUMO}

Percevejos predadores alimentando em diferentes níveis tróficos tem despertado o interesse para o entendimento da ecologia e papéis exercido no controle biológico por esses predadores. Os parâmetros que governam o comportamento alimentar onívoro desses predadores tem sido auxiliado pelos estudos sobre enzimas de glândula salivares. A variabilidade de enzimas em percevejos predadores tem sido sugerido como adaptação básica para a convergência ou divergência para a onivoria. Assim, enzimas salivares de percevejos predadores tem fornecido entendimento, ao menos parcial, da alternância de alimentação entre plantas e animais. Neste estudo, foi utilizado a presença de enzimas como variáveis canônicas para atribuir a cada espécie estudada predominância do comportamento alimentar baseado na combinação das enzimas salivares secretadas. A enzima pectinase tem sido específica para espécies fitófagas, portanto, sendo considerada variável de separação e, fosfolipase e tripisina como indicadoras de adaptações para predação, enquanto amilase e peptidase como indicativo para onivoria pois são encontradas tanto em espécies fitófagas e predadoras. Assim, sendo essas usadas como explicação para adaptação em percevejos predadores alimentarem de plantas (amilase) e percevejos fitófagos alimentarem de presas (peptidase).

\section{REFERENCES}

Agrawal, A. A. (2003), Why omnivory? Ecology 84, 25212567.

Agusti, N. and Cohen A.C. (2000), Salivary and anterior mid-gut digestive enzymes from Lygus hesperus and $L$. lineolaris. J. Entomol. Sci. 35, 176-186.
Alomar, O. and Albajes, R. (1996), Greenhouse whitefly (Homoptera: Aleyrodidae) predation and tomato fruit injury by the zoophytohagous predator Dicyphus tamaninii (Heteroptera: Miridae). In: Alomar, O. and Wiedenmann, R.N. (Eds.). Zoophytophagous Heteroptera: implications for life history and integrated pest management, Lanham: Entomological Society of America. pp. 55-177.

Applebaum, S. W. (1985), Biochemistry of digestion. In: Kerkut, G. A. and Gilbert, L. I. (Eds.). Comprehensive insect physiology, biochemistry, and pharmacology, New York: Pergamon Press. pp. 279-311.

Armer, C. A.; Wiedenmann, R. N. and Bush, D. R. (1998), Plant feeding site selection on soybean by the facultatively phytophagous predador Orius insidiosus. Entomol. Exp. Appl. 86, 109-118.

Ashouri, A.; Overney, S.; Michaud, D. and Cloutier, C. (1998), Fitness and feeding are affected in the twospotted stinkbug, Perillus bioculatus, by the cysteine proteinase inhibitor, oryzacystatin I. Arch. Insect Biochem. Physiol. 38, 74-83.

Azevedo, D. O.; Zanuncio, J. C.; Zanuncio Jr. J. S.; Martins, G. F.; Marques-Silva, S.; Sossai, M. F. and Serrão, J. E. (2007), Biochemical and morphological aspects of salivary glands of the predator Brontocoris tabidus (Heteroptera: Pentatomidae). Brazilian Arch. Biol. Technol. 50, 469-477.

Bell, H. E.; Down, R. E.; Fitches, E. C.; Edwards, J. E. and Gatehouse, A. M. R. (2003), Impact of genetically modified potato expressing plant-derived insect resistance genes on the predatory bug Podisus maculiventris (Heteroptera: Pentatomidae). Biocontr. Sci. Technol. 13, 729-741.

Boyd Jr, D. W. (2003), Digestive enzymes and stylet morphology of Deraeocoris nigritulus (Uhler) (Hemiptera: Miridae) reflect adaptations for predatory habits. Ann. Entomol. Soc. Am. 96, 667-671.

Boyd Jr, D. W.; Cohen, A. C. and Alverson, D. R. (2002), Digestive enzymes and stylet morphology of Deraeocoris nebulosus (Hemiptera: Miridae), a predacious plant bug. Ann. Entomol. Soc. Am. 95, 395-401.

Campbell, B. C. and Shea, P. J. (1990), A simple staining technique for assessing feeding damage by Leptoglossus occidentalis Heidemann (Hemiptera, Coreidae) on cones. Can. Entomol. 122, 963-968.

Cobben, R. H. (1978), Evolutionary trends in Heteroptera. Part II. Mouthpart-structures and feeding strategies. Wageningen: Mededelingen Landbouwhogeschool.

Cohen, A. C. and Hendrix, D. L. (1992), Determination of trophic enzymes in Bemisia tabaci (Gennadius). In: Proceeding of Beltwide Cotton Conferences, v.2. Memphis: National Cotton Council of America. pp. 951952. 
Cohen, A. C. and Wheeler, A. G. (1998), The role of saliva in the highly destructive fourlined plant bug (Hemiptera: Miridae: Mirinae). Ann. Entomol. Soc. Am. 91, 94-100.

Cohen, A. C. (1990), Feeding adaptations of some predaceous Hemiptera. Ann. Entomol. Soc. Am. 83, 12151223.

Cohen, A. C. (1993), Organization of digestion and preliminary characaterization of salivary trypsin-like enzymes in a predaceous heteropteran, Zelus reinardii. $J$. Insect Physiol. 39, 823-829.

Cohen, A. C. (1995), Extra-oral digestion in predaceous terrestrial arthropoda. Annu. Rev. Entomol. 40, 85-103.

Cohen, A. C. (1996), Plant feeding by predatory Heteroptera: evolutionary adaptational aspects of trophic switching. In: Alomar, O. and Wiedenmann, R. N. (Eds.). Zoophytophagous Heteroptera: implications for life history and integrated pest management. Lanham: Entomological Society of America, Lanham. pp. 1-7.

Cohen, A. C. (1998a), Solid-to-liquid feeding: the insect(s) stroy of extra-oral digestion in predaceous arthropoda. Am. Entomol. 44, 103-116.

Cohen, A. C. (1998b), Biochemical and morphological dynamics and predatory feeding habitats in terrestrial Heteroptera. In: Coll, M. and Ruberson, J. R. (Eds.) Predatory Heteroptera: their ecology and use in biological control. Lanham: Entomological Society of America, Lanham. pp. 21-32.

Cohen, A. C. (2000), How carnivorous bugs feed. In: Schaefer, C. W. and Panizzi, A. R. (Eds.). Heteroptera of economic importance. Boca Raton: CRC Press. pp. 563570.

Colebatch, G.; East, P. and Cooper, P. (2001), Preliminary characterization of digestive proteinases of the green mired, Creontiades dilutus (Hemiptera: Miridae). Insect Biochem. Mol. Biol. 31, 415-423.

Coll, M. (1998), Living and feeding on plants in predatory Heteroptera. In: Coll, M, and Ruberson, J. R. (Eds.) Predatory Heteroptera: their ecology and use in biological control. Lanham: Entomological Society of America. pp. 89-129.

Coll. M. and Guershon, M. (2002), Omnivory in terrestrial arthropods: mixing plant and prey diet. Annu. Rev. Entomol. 47, 267-297.

Edwards. J. S. (1961), The action and composition of the saliva of an assassin bug Platymeris rhadamantus Gaerst. (Hemiptera, Reduviidae). J. Exp. Biol. 38, 61-77.

Eubanks, M. D.; Styrsky, J. D. and Denno, R. F. (2003), The evolution of omnivory in heteropteran insects. Ecology 84, 2549-2556.

Evangelista Jr, W. S.; Gondim Jr, M. G. C.; Torres, J. B.; Marques, E. J. (2004), Fitofagia de Podisus nigrispinus em algodoeiro e plantas daninhas. Pesq. Agropec. Bras. 39, 413-420.

Ferran, A.; Rortais, A.; Malausa, J. C.; Gambier, J. and Lambin, M. (1996), Ovipositional behaviour of Macrolophus caliginosus (Heteroptera: Miridae) on tobacco leaves. Bull. Entomol. Res. 86, 123-128.
Freitas, S.P.C.; Evangelista Junior, W.S., Zanuncio, J.C. and Serrão J.E. (2006) Development, survival and reproduction of Podisus nigrispinus (Dallas, 1851) (Heteroptera: Pentatomidae) with salt and amino acids solutions supplementary diet. Brazilian Arch. Biol. Technol. 49, 449-455.

Gillespie, D. R. and McGregor, R. R. (2000), The functions of plant feeding in the omnivorous predator Dicyphus hesperus: water places limits on predation. Ecol. Entomol. 25,380-386.

Haridass, E. T. and Ananthakrishnan, T. N. (1981), Functional morphology of the salivary system in some Reduviidae (Insecta-Heteroptera). Proc. Indian Acad. Sci. $B$ 90, 145-160.

Hori, K. and Miles, P. W. (1993), The etiology of damage to Lucerne by the green mirid, Creontiades dilutus (Stål). Australian J. Exp.l Agric. 33, 327-331.

Hori, K. (1975), Digestive carbohydrases in the salivary gland and midgut of several phytophagous bugs. Comp. Biochem. Physiol. B 50, 145-151.

Hori, K. (2000), Possible causes of disease symptoms resulting from the feeding of phytophagous Heteroptera. In: Schaefer, C. W. and Panizzi, A. R. (Eds.). Heteroptera of economic importance. Boca Raton: CRC Press. pp. 1135.

Klowden, M. J. (2002), Physiological systems in insects. San Diego: Academic Press.

Konarev, A. V. (1996), Interaction of insect digestive enzymes with plant protein inhibitors and host-parasite coevolution. Euphytica 92, 89-94.

Laurema, S.; Varis, A. L. and Miettinen, H. (1985), Studies on enzymes in the salivary glands of Lygus rugulipennis (Hemiptera: Miridae). Insect Bioch 15, 211-224.

Miles, P. W. (1972), The saliva of Hemiptera. Adv. Insect Physiol. 9, 183-255.

Naranjo, S. E. and Stimac, J. L. (1985), Development, survival, and reproduction of Geocoris punctipes (Hemiptera: Lygaeidae): effects of plant feeding on soybean and associated weeds. Environ. Entomol. 14, 523-530.

Oliveira, E. J. M.; Torres, J. B.; Carrano-Moreira, A. F. and Barros, R. (2002), Efeito das plantas do algodoeiro e do tomateiro, como complemento alimentar, no desenvolvimento e na reprodução do predador Podisus nigrispinus (Dallas) (Heteroptera: Pentatomidae). Neotrop. Entomol. 31, 101-108.

Oliveira, J. A.; Oliveira, M. G. A.; Guedes, R. N. C. and Soares, M. J. (2006) Morphology and preliminary enzyme characterization of the salivary glands from the predatory bug Podisus nigrispinus (Heteroptera: Pentatomidae). Bull. Entomol. Res. 96, 251-258.

Oppert, B. (2001), Transgenic plants expressing enzyme inhibitors and the prospects for biopesticide development. In: Koul, O. and Dhaliwal, G. S. (Eds.). Phytochemical biopesticides. Amsterdam: Harwood Academic Publishers. pp. 83-95. 
Rastogi, S. C. (1962), On the salivary enzymes of some phytophagous and predaceous heteropterans. Sci. Cult. 28,479-480.

Ruberson, J. R.; Tauber, M. J. and Tauber, C. A. (1986), Plant feeding by Podisus maculiventris (Heteroptera: Pentatomidae): effect on survival, development, and preoviposition period. Environ. Entomol. 15, 894-897.

Saint-Cyr, J. F. and Cloutier, C. (1996), Prey preference by the stinkbug Perilus bioculatus, a predator of the Colrado potato beetle. Biol. Control 7, 251-258.

Saleh, A. and Sengonca, S. (2001), Life table of the predatory bug Dicyphus tamaninii Wagner (Het., Miridae) by feeding on Aphis gossypii Glover (Hom., Aphididae) as a prey. Zeitsch. Pfl. Pflanzens. 6, 608615.

SAS Institute, (1999-2001), SAS/STAT User's guide, version 8.02, TS level $2 \mathrm{MO}$. Cary: SAS Institute Inc.

Stamopoulos, D. C.; Diamantidis, C. and Chloridis, A. (1993), Activités enzymatiques du tube digestif du prédateur Podisus maculiventris (Hem.: Pentatomidae). Entomophaga 38,493-499.

Stoner, A. (1970), Plant feeding by a predaceous insect, Geocoris punctipes. J. Econ. Entomol. 63, 19111915.

Strong, F. E. and Kruitwagen, E. C. (1968), Polygalacturonase in the salivary apparatus of Lygus hesperus (Hemiptera). J. Insect Physiol. 14, 1113-1119.

Swart, C. C. and Felgenhauer, B. E. (2003), Structure and function of the mouthparts and salivary gland complex of the giant waterbug, Belostoma lutarium (Stål) (Hemiptera: Belostomatidae). Ann. Entomol. Soc. Am. 96, 870-882.

Tamaki, G. and Butt, B. A. (1978), Impact of Perillus bioculatus on the Colorado potato beetle and plant damage. Washington: United State Department of Agriculture Technical Bulletin no. 1581.

Terra, W. P. (1990), Evolution of digestive system of insects. Annu. Rev. Entomol. 35, 181-200.
Terra, W. R. and Ferreira, C. (1994), Insect digestive enzymes: properties, compartmentalization and function. Comp. Biochem. Physiol. B 109, 1-62.

Thie, N. M. R and Houseman, J. G. (1990), Identification of cathepsin $\mathrm{B}, \mathrm{D}$ and $\mathrm{H}$ in the midgut of Colorado potato beetle, Leptinotarsa decemlineata Say (Coleoptera: Chrysomelidae). Insect Biochem. 20, 313-318.

Thummel, C. S. and Chory, J. (2002), Steroid signaling in plants, and insects - common themes, different pathways. Genes Develop. 16, 3113-3129.

Torres, J. B.; Zanuncio, J. C. and Moura, M. A. (2006), The predatory stinkbug Podisus nigrispinus: biology, ecology and augmentative releases for lepidoperan larval control in Eucalyptus in Brazil. Persp. Agric. Vet. Sci. 15, 1-16.

Valenzuela, J. G. and Ribeiro, J. M. C. (1998), Purification and cloning of the salivary nitrophorin from the hemipteran Cimex lectularius. J. Exp. Biol. 201, 26592664.

Valicente, F. H. and O'Neil, R. J. (1995), Effects of host plants and feeding regimes on selected life history characteristics of Podisus maculiventris (Say) (Heteroptera: Pentatomidae). Biol. Control 5, 449-461.

Wheeler, A. G. (2000), Predacious plant bugs (Miridae). In: Schaefer, C. W. and Panizzi, A. R. (Eds.). Heteroptera of economic importance. Boca Raton: CRC Press. pp. 657693.

Zeng, F. and Cohen, A. C. (2000a), Comparison of $\alpha$ amylase and proteinase activities of a zoophytophagous and two phytozoophagous Heteroptera. Comp. Biochem. Physiol. A 126,101-106.

Zeng, F. and Cohen, A. C. (2000b), Demonstration of amylase from the zoophytophagous anthocorid Orius insidiosus. Arch. Insect Biochem. Physiol. 44, 136-139.

Received: April 15, 2007; Revised: November 16, 2007; Accepted: May 24, 2009. 